\title{
THE STUDY OF SORPTION OF THE MILK IONIZED CALCIUM BY SODIUM ALGINATE
}

\author{
Raisa Plotnikova \\ Department of Food Technologies \\ Kharkiv State University of Food Technologies and Trade \\ 333 Klochkivska str., Kharkiv, Ukraine, 61051 \\ raisa17_86@mail.ru \\ Nataliya Grynchenko \\ Department of Meat Processing Technologies \\ Kharkiv State University of Food Technologies and Trade \\ 333 Klochkivska str., Kharkiv, Ukraine, 61051 \\ hduht@kharkov.com \\ Pavlo Pyvovarov \\ Department of Food Technologies \\ Kharkiv State University of Food Technologies and Trade \\ 333 Klochkivska str., Kharkiv, Ukraine, 61051
}

\begin{abstract}
The possibility of regulation of defatted cow milk salt composition (fat content - 0,05\%) with the use of sodium alginate as a natural ion-exchanger was studied. Realization of the properties of sodium alginate as to the bounding of calcium ions allows receive the systems on the base of cow milk, stable in time and at the thermal processing. The studies established the influence of technological factors on the sorption of ionized calcium by the solution of complex-creator by sodium alginate. It was established, that the important factors that influence the process are the active acidity and conditions of the process, namely, the phased addition of sorbent that favors the equal speed of process and, as the result, the equal speed of sorption during the whole process. At the same time the study of influence of sorption area and temperature demonstrates that these factors are not determining ones in this process. It was established, that rationalization of parameters of ionized calcium sorption results in the raise of thermal stability of defatted cow milk and the systems on its base. Materials, given in the work, are the base for elaboration and introduction of technology of dessert production (ice-cream, creams, puddings, cocktails and so on), in which composition the colloid stability is provided at the joint use of milk and fruit-berry raw material that can be used in food industry.

Keywords: defatted cow milk, complex-creator, sodium alginate, ionized calcium, sorption of ionized calcium of defatted cow milk.

\section{Introduction}

The joint use of defatted milk (fat content $-0,05 \%$ ) and fruit-berry raw material is interesting taking into account the creation of food systems with new consumption properties. But such food system is not stable in time and at thermal processing because of functional-technological properties of proteins of casein fraction. According to the literary data [1-3], at decrease of the active acidity $(\mathrm{pH})$ in the result of addition of acid-containing raw material the displacement of colloid system balance and the loss of stability take place that is attended by stratification of the system. The studies of the scientists [3-6] established that the important factor at $\mathrm{pH}$ decrease is ionized calcium accumulation that is released from calcium-containing salts of colloid phase and takes part in milk proteins coagulation at thermal processing. The literature $[6,7]$ contains the reference on the fact that the calcium transfer from ionized state to the calcium-containing compounds and/or its removal result in the increase of acid and thermal stability of defatted milk. The studies revealed the expedience of the sodium alginate usage that is able to bound the calcium ions $[8,9]$ creating gel that can be removed from defatted milk or systems on its base.
\end{abstract}


Technological principles of sodium alginate usage as ion-exchanger for increasing the colloid stability of defatted milk is not completely studied for today. Taking into account this fact it is expedient to study the sorption of ionized calcium of defatted milk by sodium alginate.

\section{Materials and Methods}

The solutions AlgNa (AlgNa of FD 127, producer - Danisco, Denmark) were received according to the producer's recommendations in correspondence to the process parameters that allow maximally provide the solution of sodium alginate and activation of its functional-technological properties. At the same time the necessary solution was prepared by dispersion of AlgNa batch in deaerated and demineralized drink water at the temperature $18 \ldots 20^{\circ} \mathrm{C}$ during $(3 \ldots 4) \times 60 \mathrm{~s}$ on magnetic mixer (Berd electromechanical plant, Russia) with further keeping during $24 \times 60^{2} \mathrm{~s}$. The received $\mathrm{AlgNa}$ solution was placed in vacuum-desiccator (Kartell, Italy) and degassed during (30...60) $\times 60 \mathrm{~s}$.

At the studies the increase of active acidity was realized by addition of acid-containing raw material, chlorine acid $(\mathrm{HCl})$ that was added to the milk as $1 \mathrm{n}$ of solution. Determination of active acidity was carried out on portative $\mathrm{pH}$-meter, made by Knick (Germany).

The sorption of ionized calcium in most studies (except the ones about the influence of sorption area, where the sorbent was added by both drop way and as a layer) was realized by the drop addition of AlgNa solution with volume $10,20,30 \mathrm{ml}$ to $100 \mathrm{ml}$ of milk at the different values of $\mathrm{pH}$ $(6,6,6,0,5,5,5,0)$. The systems were kept during $0,5 \cdot 60^{2} \mathrm{~s}-24 \cdot 60^{2}$ creating gel «AlgNa-Ca» that was eliminated by decantation.

At the study of influence of the process phasing AlgNa solution with determined mass $10 \mathrm{~g}$ (that provides concentration sufficiency of sodium alginate relative to the free ions of milk calcium for realization of gel-creation) (1 stage) was added to the milk at the active acidity of defatted cow milk $-6,6$ and 5,5 kept during $3 \cdot 60^{2} \mathrm{~s}$. Then the system was divided in two parts, in one the added AlgNa solution was left for further sorption for $21 \cdot 60^{2} \mathrm{~s}$, and the new portion of AlgNa solution with mass $10 \mathrm{~g}$ was added to the other (II stage) then sorption was carried out during $3 \cdot 60^{2} \mathrm{~s}$. In studied system the change of $\mathrm{Ca}^{2+}$ was analyzed by the following division of the system. In further $10 \mathrm{~g}$ of AlgNa solution was added again to the one part for sorption during $3 \cdot 60^{2} \mathrm{~s}$ (III stage) and the other part was left for $21 \cdot 60^{2} \mathrm{~s}$. In all samples, left for the further sorption for $21 \cdot 60^{2} \mathrm{~s}$ the calcium content was also established for comparison. In the studies where not only complex-creator but also acid-containing raw material were added step-by-step, besides the addition of sodium alginate solution the acid-containing raw material ( $1 \mathrm{n}$ solution of $\mathrm{HCl}$ ) was added by the drop way at mixing in volume, necessary for the decrease of active acidity to $\mathrm{pH} 5,5$.

The determination of calcium quantity in milk was realized using complexonometric titration, based on interaction between calcium and trilon B in alkali medium, in which result calcium transfers from the compounds with proteins and phosphorus to the solution. The rest of trilon B was titrated by the calcium chloride solution [10]. The mass part of ionized calcium in studied samples was determined by potentiometric method using calcium-selective electrode [11].

The thermal stability of food systems was determined by alcoholic assay. The method is based on milk proteins coagulation under the effect of ethyl alcohol. Its essence is in addition of the water solution of ethyl alcohol (volume $-2 \mathrm{ml}$ ) at the different concentration $(68 \%, 70 \%, 72 \%$, $75 \%$ ) to the studied samples with volume $2 \mathrm{ml}$. If the protein component coagulation did not take place, the systems were considered as thermostable ones.

Experimental procedures were carried out in scientific laboratories of Kharkiv state university of food and trade an institute of microbiology and virology, named after D. K. Zabolotny, NAS of Ukraine.

\section{Results}

On the base of studies it was established, that under conditions of using AlgNa solution of $1,0 \%$ concentration, the maximal quantity of sorbed calcium of the general one is $10,3 \pm 0,1 \%$, at concentration $2,0 \%-11,7 \pm 0,1 \%$. The increase of general content of complex-creator leads to the increase of sorbed $\mathrm{Ca}^{2+}$ quantity. The addition of $1,0 \% \mathrm{AlgNa}$ solution at the milk:AlgNa solution ratio as 100:10 leads to the sorption $4,17 \pm 0,03 \% \mathrm{Ca}^{2+}$, and at the ratio 100:20 - 10,3 $\pm 0,1 \%$. It was 
established, that under conditions of addition of the equal quantity of $\mathrm{AlgNa}(0,2 \mathrm{~g})$ in solutions of $1,0 \%$ concentration at the ratio $100: 20$ and $2,0 \%$ concentration at the ratio 100:10 to the milk leads the sorption of relatively less quantity of $\mathrm{Ca}^{2+}-10 \%$ and $8 \%$ respectively.

The regularities of kinetics of sorption of $\mathrm{Ca}^{2+}$ of defatted milk by AlgNa solution depending on the sorption area were established (Table 1) after exposition during $6 \cdot 60^{2} \mathrm{~s}$. The different sorption area was attained by the drop and layer addition of AlgNa solution at the milk : sodium alginate solution ratio as 100:10.

Table 1

Kinetics of sorption of $\mathrm{Ca}^{2+}$ of defatted milk by AlgNa solution depending on the sorption area

\begin{tabular}{ccc}
\hline $\mathbf{S}_{\text {sorption }}, \mathbf{m}^{\mathbf{2}}$ & $\mathbf{C a}^{2+}$ content, $\mathbf{~ m g \%}$ & \\
& At AlgNa concentration 1,0 \% & At AlgNa concentration 2,0 \% \\
\hline $3,0 \cdot 10^{-3}$ & $115,5 \pm 1,0$ & $115,0 \pm 1,0$ \\
$15,0 \cdot 10^{-3}$ & $111,5 \pm 1,0$ & $110,9 \pm 1,0$
\end{tabular}

PH decrease from 6,0 to 5,5 leads to the increase of the sorption speed. It was established, that the sorption speed at $\mathrm{pH}$ decrease from 6,0 to 5,0 increases in 2,5 times: at $\mathrm{pH}$ 6,0 and 5,0 the sorption speed is $0,4 \cdot 10^{-3} \% / \mathrm{s}$ and $1,0 \cdot 10^{-3} \% / \mathrm{s}$ respectively and the general quantity of calcium that is sorbed during $6 \cdot 60^{2} \mathrm{~s}$, is $9,3 \%$ and $21,5 \%$ to the initial content respectively.

The inertia of bounding of ionized calcium does not allow intensify the sorption process. The effective solution is phased addition of complex-creator and acid-containing raw material to the system. It was established, that at sorption $\left(\tau=9 \cdot 60^{2} \mathrm{~s}, \mathrm{pH} 5,5\right)$ the general content of calcium at phased addition of $\mathrm{AlgNa}$ solution decreases to $90,7 \pm 0,1 \mathrm{mg} \%$. The phased addition of $\mathrm{AlgNa}$ solution and solubility correctors to the system favors the calcium decrease to $88,0 \pm 0,1 \mathrm{mg} \%$.

The temperature influence on the sorption process where it was determined that at temperature $2{ }^{\circ} \mathrm{C}$ and $40{ }^{\circ} \mathrm{C}$ the general content of calcium in defatted milk ( $\left.\mathrm{pH} 5,5\right)$ decreases from $120,0 \pm 1,0 \mathrm{mg} \%$ to $89,0 \pm 0,7 \mathrm{mg} \%$ and $86,0 \pm 0,7 \mathrm{mg} \%$ respectively was established. Taking into account the received results and stability of the studied system it is priority to carry out the $\mathrm{Ca}^{2+}$ sorption process at the temperature $2 \ldots 6^{\circ} \mathrm{C}$.

The process of regulation of salt system composition of the milk leads to the raise of its colloid stability that, in its turn, favors the formation of more thermostable systems. (Table 2).

Table 2

The thermal stability of milk with regulated salt system composition depending on sorbed $\mathrm{Ca}^{2+}$ quantity

\begin{tabular}{|c|c|c|c|c|c|c|c|c|c|c|}
\hline \multirow{2}{*}{ Alcohol concentration, $\%$} & \multicolumn{10}{|c|}{ The thermal stability of milk depending on sorbed $\mathrm{Ca}^{2+}$ quantity, \% } \\
\hline & 0 & 10 & 11 & 13 & 15 & 18 & 19 & 20 & 23 & 26 \\
\hline 68 & - & + & + & + & + & + & + & + & + & + \\
\hline 70 & - & - & - & - & + & + & + & + & + & + \\
\hline 72 & - & - & - & - & - & - & - & + & + & + \\
\hline 75 & - & - & - & - & - & - & - & - & - & - \\
\hline
\end{tabular}

Regulation of the salt system composition of defatted milk leads to the decrease of calcium content that takes place at the expense of ionized calcium. The establishing of new balance under conditions of addition of sodium alginate causes the release of $\mathrm{Ca}^{2+}$ that is probably contained in calcium-including salts. This fact is proved by the received data where under conditions of $\mathrm{Ca}^{2+}$ sorbtion by the complex-creator, the decrease of $\mathrm{Ca}^{2+}$ in defatted milk is from $120,0 \pm 1,0 \mathrm{mg} \%$ to $110,5 \pm 1,0 \mathrm{mg} \%$, the changes of calcium content in real solution from $94,0 \pm 0,9 \mathrm{mg} \%$ to $78,5 \pm 0,7 \mathrm{mg} \%$. At the same time the content of calcium, combined with casein at regulation of the salt system composition is $27,4 \pm 0,2 \mathrm{mg} \%$ not depending on the process duration . 


\section{Conclusions}

It was established, that determining factor of the sorption is the sodium alginate concentration and the milk:AlgNa solution ratio. It was proved, that the sorption of ionized calcium of defatted milk at the grounded parameters allows receive the food systems with the high thermal and acid stability parameters.

The testing of the offered method was carried out within realization of technology of icecream (city Kharkiv, CC "Khladoprom") and also creams and cocktails (city Kharkov, PE "Kobzar-65") production.

The complex of scientific works fully opens the prospects of this direction in the area of coagulation processes of defatted milk and production of the protein products, based on the milk with regulated salt system composition.

\section{References}

[1] Singh, H. (2004). Heat stability of milk. International Journal of Dairy Technology, 57 (2-3), 111-119. doi: 10.1111/j.1471-0307.2004.00143.x

[2] Faka, M., Lewis, M. J., Grandison, A. S., Deeth, H. (2009). The effect of free Ca2+ on the heat stability and other characteristics of low-heat skim milk powder. International Dairy Journal, 19 (6-7), 386-392. doi: 10.1016/j.idairyj.2008.12.006

[3] Tepel, A. (2012). Chemistry and physics of milk. Saint Petersburg: Profession, 824.

[4] Philippe, M., Legraet, Y., Gaucheron, F. (2005). The effects of different cations on the physicochemical characteristics of casein micelles. Food Chemistry, 90 (4), 673-683. doi:10.1016/j.foodchem.2004.06.001

[5] Post, A. E., Arnold, B., Weiss, J., Hinrichs, J. (2012). Effect of temperature and pH on the solubility of caseins: Environmental influences on the dissociation of $\alpha \mathrm{S}$ - and $\beta$-casein. Journal of Dairy Science, 95 (4), 1603-1616. doi: 10.3168/jds.2011-4641

[6] Tanashuk, S., Savchenko, O., NIkolaych, A. (2006). Zastosuvaniya ionoobmennuh smol. Harchova i pererobna promuslovist, 2, 23-25.

[7] Sokolova, L. I. (1975). Application of ion exchange processes for improving the thermal stability of milk. Moscow: Moscow Technological Institute of Meat and Dairy Industry, 21.

[8] Donskaya, G. V., Drozhzhin, V. M., Grivkova, A. I. (1998). Izbiratelnue sorbentu rastitelnogo proishogdeniya dlya ochistki moloka ot stronziya. Molochnaya promushlennost, 1, 31-32.

[9] Alekseeva, N. U., Aristova, V. P., Patratsiy, A. P. (1986). Sostav i svoistva moloka kak surya dlya molochnoy promushlennosti. Moscow: Agropromizdat, 239.

[10] Deynychenko, G. V. (1997). Scientific rationale and development of technologies foodstuffs Increased values of food based on low-fat raw milk. Kharkov: Kharkiv State Academy of technology and organization food, 33 . 